\title{
Improving the Competitiveness of Enterprises Operating in the Construction Services Market
}

\author{
Elena Pesotskaya ${ }^{1 *}$, Larisa Selyutina $^{2}$, Boris Kuznetsov ${ }^{3}$ \\ ${ }^{1}$ Department of Economics and Management in Services, Saint-Petersburg State University of \\ Economics, 21, Sadovaya str., St. Petersburg 191023, Russia \\ ${ }^{2}$ Department of Economics and Construction Management, Emperor Alexander I St. Petersburg State \\ Transport University, 9, Moskovsky pr., St. Petersburg 190031, Russia \\ ${ }^{3}$ Department of Construction Economics and Housing and Utility Infrastructure, Saint-Petersburg \\ State University of Architecture and Civil Engineering, 2-ya Krasnoarmeiskaya str. 4, St. Petersburg \\ 190005, Russia
}

\begin{abstract}
The purpose of the study is to analyze the tools that exist today to improve the competitiveness of companies in the Russian construction and repair services market, which promote their progressive development from the perspective of partnership management. The competitors' ambition to establish, maintain, develop and utilize their own advantages and to simplify the competitive environment is realized through the establishment of interaction between the competing subjects, which can be legally identified as a competitive partnership. The authors consider the possibility of establishing a competitive partnership in the context of horizontal merger and network associations as part of the investment-andconstruction complex. This research describes the proposals for expanding the practical scope of partnership at the construction services market as a factor of improving the competitiveness level of enterprises on the basis of using strategic approaches to managing production and economic activities and improving the marketing business process support.
\end{abstract}

\section{Introduction}

The present-day period of the economic and social development of the Russian Federation and its regions is relate to the active implementation of principles and methods of entrepreneurship in all sectors and spheres of the economic complex. Entrepreneurship has gained a strong position as a high impact activity capable qualitatively transform production and business processes, giving them an innovative impetus, creating conditions for further practical use of competitive incentives in managing these processes [1-6].

Entrepreneurial activity realizes its properties, its distinctive features in a competitive environment. The entrepreneurial environment, due to its economic nature, forms the preconditions for an active competitive process, all participants of which, acting as subjects of competition, realize their own competitive potential, develop it through an increase in

*Corresponding author: epes2@mail.ru 
competitive advantages, use methods of strategic and tactical management in solving problems of managing competitiveness [7-10].

It is worth emphasizing that the current stage of Russian economic development is marked by the existence of a well-defined vector and that is the focus on innovative development. This implies that competition should be regarded from innovation perspectives nowadays by focusing on its inherent innovative incentives and their forms of occurrence in various sectors and business fields and, particularly, in the construction sector that covers small, medium, and large enterprises.

In addition, there is a need to develop approaches to competitiveness management, which are only preliminarily addressed under strategic enterprise development as one of the highly inexplicit factors $[11,12]$. The objectivity of the noted and a number of other problems makes it possible to formulate quite specific tasks facing modern entrepreneurship, the solution of which is a necessary condition for bringing Russian entrepreneurship to a higher quality level. These tasks include, firstly, the need to increase the competitiveness of business entities and the intensity of the competitive process that stimulates their initiatives, and, secondly, the needs to ensure the innovativeness of these initiatives as a real precondition for modifying competition, giving it a progressive transformation function $[13,14]$.

In this context, the need to systematize, continue and deepen the research of a competitive subject and to study the fundamental basics of competition and the mechanisms that influence the entrepreneurial process is becoming reasonably required. The above factors show that the subject of this study is of great interest.

\section{Materials and Methods}

The competitive advantage of entrepreneurial structures is largely determined by the specifics of their activities and sectoral development trends within the market of the national economy. And, the service sector is no exception here, given the fact that it is undergoing significant transformations in connection with the digital transformation of business and the transition of the economy to an innovative path of development. The construction services market must be justly recognized as one of the key service economy sectors whose sustainable growth ensures the progressive development of the entire economic system [15].

According to the latest large-scale changes in the activities of the SRO, which went into effect the third quarter of 2017, an important innovation is the mandatory presence of at least two employees in the staff of a construction company that is a member of the SRO, who meet the established qualification requirements for specialists in organizing the execution of construction and reconstruction works, overhaul of capital construction objects, and are entered on the National Register of Construction Specialists.

It should be noted that the National Register of Specialists performs an important task to track the availability of qualified workers among SRO members, as well as to assess the human potential of a particular construction company, which undoubtedly has a real impact on the change in its level of competitiveness in the context of human capital development. At the moment, there are almost 59 thousand pending applications (the expected number of applications is estimated at 140-160 thousand) [16].

According to the annual rating published by the Doing Business World Bank, Russia has improved by 22 ranks in terms of "Obtaining construction permits". Today, Russia holds the 26-th rank among the 190 rated countries [17]. At the same time, the World Bank experts working on the rating took into account the new data by the Russian Ministry of Construction on the work to reduce procedures in construction (the time limits for issuing construction permits was 7 days, and land plot development plans - 20 days). Currently, at 
the national level, work continues to optimize the process of passing conciliation and other procedures in the field of construction, while the issuance of construction permits will be considered within five days $[18,19]$. According to experts, in order to obtain a permit for the construction of a small non-industrial building in Russia, today you will have to go through a fairly large number of conciliation procedures (about 13) within 165 days at a cost of $1.1 \%$ of the cost of such an object.

It can be stated that the positive changes in the performance of the Russian construction services market have a direct effect on the formation and the development of the competitiveness management system for national enterprises. In Figure 1, the authors present positive trends in the development of the Russian construction services market in the context of the impact on the level of competitiveness of business structures.

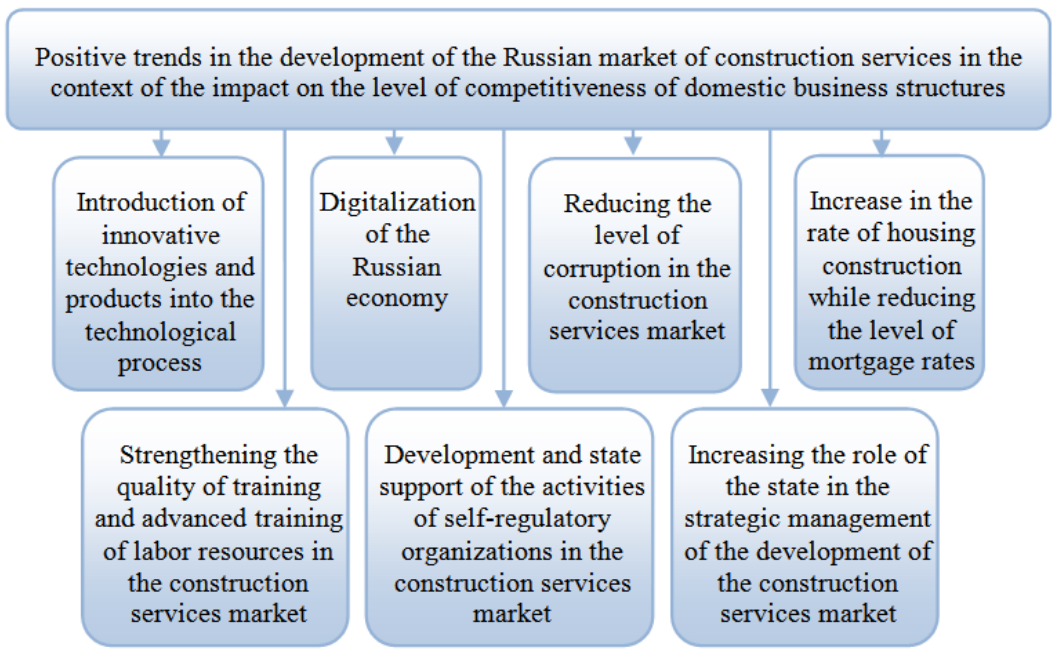

Fig. 1. Positive trends in the development of the Russian market of construction services in the context of the impact on the competitiveness of domestic business structures

\section{Results and discussion}

According to the authors, the following aspects of partnership relations are most important from the perspective of managing the competitiveness of companies in the Russian construction and repair services market: public-private partnership (partnership relations between enterprises and public authorities), customer-oriented policies (partnership relations between enterprises and service consumers) and competitive partnership (formation of cluster structures at the construction services market).

Such a promising format of interaction between business and government as a publicprivate partnership is a driver of growth in the competitiveness of enterprises that have entered into partnerships within a specific market [20,21]. In the context of the formation of the optimal combination of the public and private sectors in the Russian construction services market, we present a number of recommendations for increasing the level of interaction between these market entities:

1. In order to provide the company with the best opportunities to overcome the forces of competition during the preparation and passing of competitive procedures, it is advisable to optimize the cost of the repair and construction services provided, in particular, to reduce it based on the introduction of new progressive building materials into production and the effective mastering of innovative technologies in the production process. 
2. To form effective business communications, to track their dynamics over time, to transform them in accordance with a competitive strategy, increased attention should be given to the qualification and competence growth of construction personnel, considering the development of their professional knowledge and skills, the use of the continuous education system in the framework of production activities as the main source of growth in the quality component of the construction services sector.

3. To maintain business partnerships that meet the benefit of both entities and mutually beneficial implementation of the concession, it is important for public and private business structures to focus on the strategy of long-term cooperation with suppliers of construction products and services.

4. The multifactorial nature, the complexity of interrelationships and the need to make the most optimal decisions require the use of a strategy to expand the range of core business as part of the formation of a multifunctional orientation of the provided construction and array of services with penetration into other industries and the markets of other regions.

5. The use of progressive forms and methods of management, the achievement of balance and full resource provision of adequate solutions in the field of strategic and operational-tactical management of entrepreneurial organizations

6. Improving the reputation level of the business structure by increasing the number of projects successfully implemented on the principles of active interaction between the state and the private sector.

7. Expansion of opportunities for the use of digital technologies, designed in the near future to completely change the operational design of public-private partnerships.

8. A special place belongs to the opportunities to use the system of benefits, whose stimulating effect is most noticeable in relation to the development of strategic guidelines for the development of entrepreneurial organizations, based on the results of their participation in public-private partnerships.

9. The need to create and organize operational access to information containing data necessary for analyzing the potential opportunities for private business to participate in public-private partnership projects, both in functional and territorial aspects.

The development of construction business customer loyalty on a regular and a mutually beneficial basis should be recognized as another equally important aspect of establishing solid relationship between enterprises and external entities [22, 23]. Establishing partnerships with consumers of construction products or services (clients of construction business organizations) should be considered from the standpoint of the formation and implementation of a marketing strategy, the effectiveness of which determines a high level of competitiveness of entrepreneurial structures. The relationship between strategic marketing and the competitiveness of the entrepreneurial structures that implement it can be characterized as follows (table 1).

Table 1. Stages of forming partnerships between business structures and clients in the construction services market

\begin{tabular}{|l|l|}
\hline \multicolumn{1}{|c|}{ Stage name } & \multicolumn{1}{c|}{ Stage content } \\
\hline $\begin{array}{l}\text { Identifying customer } \\
\text { needs and requests }\end{array}$ & $\begin{array}{l}\text { Identification of client requests and problems based on the use of } \\
\text { a number of methods (questionnaires, interviews, the formation } \\
\text { of special instructions for working with clients based on ISO } \\
9001 \text { standards, etc.) }\end{array}$ \\
\hline Sales Service & $\begin{array}{l}\text { In the conditions of the construction market, it assumes a full } \\
\text { cycle of service provision - from design issues to providing the } \\
\text { necessary materials and technological equipment }\end{array}$ \\
\hline $\begin{array}{l}\text { Implementation of orders, } \\
\text { distribution }\end{array}$ & $\begin{array}{l}\text { Providing high quality services within a predetermined time } \\
\text { frame }\end{array}$ \\
\hline
\end{tabular}




\begin{tabular}{|l|l|}
\hline \multicolumn{1}{|c|}{ Stage name } & \multicolumn{1}{c|}{ Stage content } \\
\hline $\begin{array}{l}\text { Increasing the level of } \\
\text { communication }\end{array}$ & $\begin{array}{l}\text { Personal communications and conducting business negotiations, } \\
\text { determining priorities in working with a client, forming } \\
\text { compromise management decisions, searching for joint optimal } \\
\text { solutions }\end{array}$ \\
\hline $\begin{array}{l}\text { Introduction of innovative } \\
\text { building technologies and } \\
\text { the use of new building } \\
\text { materials }\end{array}$ & $\begin{array}{l}\text { Preparing the client for the possibility of introducing innovative } \\
\text { construction technologies and the use of new building materials } \\
\text { in terms of improving the quality and comfort of the facilities } \\
\text { being built }\end{array}$ \\
\hline $\begin{array}{l}\text { Formation of a customer- } \\
\text { oriented pricing policy }\end{array}$ & $\begin{array}{l}\text { Development of a diversified price offer to ensure customer } \\
\text { loyalty, calculation of the optimal amount of discounts in } \\
\text { conditions of constant interaction, the possibility of deferred } \\
\text { payment, the choice of forms and methods of payment for } \\
\text { services that are optimal from the client's point of view }\end{array}$ \\
\hline $\begin{array}{l}\text { Implementation of related } \\
\text { transactions }\end{array}$ & $\begin{array}{l}\text { Implementation of additional options related to the client's } \\
\text { activities and based on his personal requests }\end{array}$ \\
\hline $\begin{array}{l}\text { Formation of personal } \\
\text { relationships }\end{array}$ & $\begin{array}{l}\text { Ensuring the development of interpersonal communications in } \\
\text { the process of providing services }\end{array}$ \\
\hline Advertising support & $\begin{array}{l}\text { Creation and promotion of personalized advertising and other } \\
\text { means of promoting services }\end{array}$ \\
\hline After-sales service & $\begin{array}{l}\text { Providing after-sales service at a high professional level in } \\
\text { accordance with individual customer requests }\end{array}$ \\
\hline
\end{tabular}

It is known that the strategic marketing tool used in business practice depends on the marketing concept, which reflects the basic principles of market behavior of organizations in a specific segment, in a group of segments, within a geographically delineated market, etc. in international practice, in the management of domestic construction entrepreneurship, they have been using marketing concepts for more than a dozen years, formed by the founders of marketing (in particular, F. Kotler) and developed in the Russian scientific school $[24,25]$. Without going deep into all the nuances of their content (due to the wide popularity of the concepts), we note their effort to find ways of methods to ensure competitive advantages.

The concept, characterized as a production concept, is focused on cost reduction and, accordingly, the production and construction process improvement, considering this reduction as the basis for the formation of competitive advantages.

The concept, called a commodity concept in the theoretical model, focuses on providing competitive advantages to improving the quality of construction products and services.

The pricing concept is looking for additional opportunities to reduce the price of products and its use means that the business entity has made a decision to enter the sphere of price competition, to participate in the "price war" characteristic of the construction market.

The sales concept assumes the expansion and improvement of the distribution system for construction products and, especially, construction services, ensuring that quality and prices are kept at an average level.

The communicative concept focuses on the active use of advertising and commercial propaganda, considering that at any ratio of price and quality, construction products become competitive in case of intensification of methods of psychological influence on the consumer.

These concepts, for all their popularity and methodological elaboration, have a high degree of abstractness. In actual practice, their individual elements are often used, forming symbiotic (sometimes unique forms) in the formation of management decisions. In addition, the very interpretation of marketing concepts in the context of competitive advantages gave a start to the emergence of several new concepts that fully correspond to 
the conditions of the business environment of the construction market. In particular, a service concept emerged. Its feature is the provision of competitive advantages through the introduction of maintenance services of the purchased construction products. We are talking about ensuring the uninterrupted technical operation of real property (finished construction products), maintenance of the process of rendering construction services, assistance in the implementation of entrepreneurship, etc.

Under difficult conditions of construction entrepreneurship, the service concept is quite capable of providing not only additional, but also the essential competitive advantages of actually functioning business entities.

The most interesting among modern marketing concepts is the concept of interaction. Giving priority to establishment, strengthening, development and use of interaction as a competitive advantage, it is important to emphasize that they (and hence the progressiveness of the interaction concept) laid the foundation for mutually beneficial partnerships and interactions.

Revealing the essence of partnership inters, it should be noted that they are of interentities, i.e. their structure depends on the structure of the external environment of the business entities of construction entrepreneurship, in which there are two groups of entities that have the most noticeable determinative effect on these business entities. These include:

- consumers group of construction products and services (clients)

- group of competing organizations

In relation to the subjects of the first group, tools are used to establish loyalty and ensure the long of interactions (especially in relation to the construction services market). In relation to the subjects of the second group, competitive interactions are used i.e. competitive partnership.

Competitive partnership is a relatively new concept. Its meaning from the point of view of management is to transform competitors into partners, in the search for such ways of interaction with partners that could reduce the excessive intensity of competition inherent in construction entrepreneurship. Competitive partnership is not just a kind of support measure for entrepreneurs, it is an opportunity for each of them to develop and increase their potential. At the same time, this type of partnership does not contradict the fundamental laws of the market - the laws of competition, the laws in the performance of its promotional function. Competition in partnership always retains its stimulating role.

It is important to note that an industry cluster is distinguished as an independent type of economic cluster, which naturally presupposes the presence of intra-industry competitive processes and competitive interactions. Such interactions can be carried out only in the form of partnership, since otherwise the industry cluster could not exist (due to the loss of systemic features) [26]. The authors analyzed the conditions for effective interaction of cluster members operating in a competitive market (table 2).

Table 2. The main activities of the construction innovation cluster from a functional perspective

\begin{tabular}{|l|l|}
\hline \multicolumn{1}{|c|}{ Direction of activity } & \multicolumn{1}{c|}{ Content } \\
\hline $\begin{array}{l}\text { Interaction with research } \\
\text { centers and innovative } \\
\text { organizations }\end{array}$ & $\begin{array}{l}\text { Increasing the role of scientific and technical support for } \\
\text { the activities of cluster members in the construction } \\
\text { services market }\end{array}$ \\
\hline $\begin{array}{l}\text { Strengthening interaction with } \\
\text { regional and municipal } \\
\text { authorities }\end{array}$ & $\begin{array}{l}\text { Providing benefits when participating in the state order } \\
\text { system and fulfilling concession agreements by combining } \\
\text { the resource base and quality characteristics of the process } \\
\text { of rendering construction services }\end{array}$ \\
\hline $\begin{array}{l}\text { Joint participation in } \\
\text { professional competitions }\end{array}$ & $\begin{array}{l}\text { Opportunity to receive professional awards, prizes and } \\
\text { distinctions, including in the field of quality management }\end{array}$ \\
\hline $\begin{array}{l}\text { Joint participation in } \\
\text { professional competitions }\end{array}$ & $\begin{array}{l}\text { Opportunity to receive professional awards, prizes and } \\
\text { distinctions, including in the field of quality management }\end{array}$ \\
\hline
\end{tabular}




\begin{tabular}{|c|c|}
\hline Direction of activity & Content \\
\hline $\begin{array}{l}\text { Increasing the level of financial } \\
\text { stability and autonomy of } \\
\text { cluster members }\end{array}$ & $\begin{array}{l}\text { The possibility of expanding the range of financial } \\
\text { instruments to improve the efficiency of financial and } \\
\text { economic activities and ensure a balance between equity } \\
\text { and borrowed funds }\end{array}$ \\
\hline $\begin{array}{l}\text { Lobbying the interests of cluster } \\
\text { education participants in terms } \\
\text { of regulatory support for the } \\
\text { provision of construction } \\
\text { services }\end{array}$ & $\begin{array}{l}\text { Formation and updating of specialized regulations } \\
\text { governing the activities of construction clusters, changes in } \\
\text { the rules of technical supervision, construction standards, } \\
\text { etc. }\end{array}$ \\
\hline $\begin{array}{l}\text { Ensuring equal access to a } \\
\text { unified information base of } \\
\text { participants }\end{array}$ & $\begin{array}{l}\text { Expansion of the database on the main customers, suppliers } \\
\text { of construction materials and equipment, servicing } \\
\text { financial and credit institutions, etc. }\end{array}$ \\
\hline $\begin{array}{l}\text { Benefiting from a common } \\
\text { brand and a cluster brand }\end{array}$ & $\begin{array}{l}\text { Promotion of services within the framework of a single } \\
\text { brand and a common trademark, the possibility of } \\
\text { increasing the level of the advertising budget through co- } \\
\text { financing of marketing activities and PR support }\end{array}$ \\
\hline $\begin{array}{l}\text { Facilitating access to new } \\
\text { innovative products and } \\
\text { technologies }\end{array}$ & $\begin{array}{l}\text { Redistribution of cluster funds in favor of the transition to } \\
\text { innovative technologies in the production and management } \\
\text { process }\end{array}$ \\
\hline $\begin{array}{l}\text { Communication and interaction } \\
\text { between participants within the } \\
\text { cluster structure }\end{array}$ & $\begin{array}{l}\text { Development of individual projects between cluster } \\
\text { members and their industry interaction }\end{array}$ \\
\hline $\begin{array}{l}\text { Increasing the level of human } \\
\text { capital involved in the } \\
\text { implementation of cluster } \\
\text { projects }\end{array}$ & $\begin{array}{l}\text { A wide range of opportunities to increase the level of } \\
\text { human capital - from the development of professional } \\
\text { competencies within the framework of the use of joint } \\
\text { educational technologies on a common infrastructural intra- } \\
\text { cluster basis to the formation of a single digital data bank } \\
\text { on potential candidates }\end{array}$ \\
\hline $\begin{array}{l}\text { Reducing the overall level of } \\
\text { the cost of services provided }\end{array}$ & $\begin{array}{l}\text { Achieving economies of scale will allow to reduce part of } \\
\text { the costs of doing business, primarily in the context of } \\
\text { transaction costs }\end{array}$ \\
\hline
\end{tabular}

It is important to note that the competitive partnership has already acquired the necessary implementation basis. In general, the principles and approaches to the clustering process have been formed, and there is even experience in the implementation of cluster models in the Russian market. Clustering, based on the use of the advantages of intersubjective interaction, the development of the competitiveness of all its participants allows to expand the possibilities of using innovative technologies (including digital), and most importantly, to accumulate resources and ensure their direction in priority projects intended for implementation in the construction services market.

\section{Conclusions}

To summarize, it is important to emphasize that the increase in the competitiveness of entrepreneurial structures focused on the production of construction services, as well as the strengthening of their competitive positions, is determined not only by external determinants, including government policy as the main one, but also by feedback factors between entrepreneurial organizations and organizations maintaining economic independence and independence - competitors. The method of establishing such feedback is the formation and permanent development of a partnership that allows for mutually beneficial cooperation between all its participants while maintaining the stimulating role of competition. 
The desire for partnerships in the modern conditions of the construction services market is a real source of increasing competitiveness, it levels out many of the contradictions inherent in the market under consideration, eliminates negative manifestations of competition, such as reducing the potential of competing entrepreneurial organizations, replacing the development strategy with a strategy of "survival" in a competitive environment the construction services market, the dispersion of management efforts in many areas that do not have structural stability, necessary and sufficient certainty, etc. which ultimately makes it possible to give entrepreneurial activity a mutually beneficial character.

The successful solution between of subjects problems of the interaction in the studied area opens up additional opportunities for expanding innovative search in construction, organizing an active information and knowledge exchange, and effectively implementing entrepreneurial initiatives using progressive management tools.

\section{References}

1. H. W. Chesbrought, The Era of open Innovation, MIT Sloan Management Review, 44 (2003)

2. E. Trushkovskaya et al, IOP Conf. Ser.: Mater. Sci. Eng. 753, 032044 (2020)

3. T. V. Maleeva, L. G. Selyutina, Materials Science Forum, 931, 1118-1121 (2018)

4. N. V. Vasileva, L. G. Selyutina, News of higher educational institutions. Construction, 1(529), 114-118 (2003)

5. M. A. Egorova, K. O. Bulgakova, L. G. Selyutina, Modelling of investment processes in the sphere of social house building, in Proceedings of the International Conference on Innovations in science and education, 22-24 March 2017, Prague, Czech Republic (2017)

6. K.O. Bulgakova, L.G. Selyutina, Science Review, 22, 366-369 (2015)

7. L. G. Selyutina, Society Environment Development (Terra Humana), 2 (11), 212-218 (2009)

8. D. Rodrik, Journal of Economic Perspectives, 28 (1), 189-208 (2014)

9. J. Moodysson, E. Zukauskaite,. Regional Studies, 48 (2014)

10. J. Graafland, Economics, Ethics and Market (Abingdon, New York, 2007)

11. O. Egorova et al, IOP Conf. Ser.: Mater. Sci. Eng. 698, 077029 (2019)

12. A. N. Vasiliev, L. G. Selyutina, Investment and Innovation Management, 1 (1), 46-55 (2007)

13. L. G. Selyutina, Materials Science Forum, 931, 1113-1117 (2018)

14. L. Egorova et al, IOP Conf. Ser.: Mater. Sci. Eng. 687, 044005 (2019)

15. T.V. Maleeva et al, IOP Conference Series: Materials Science and Engineering, 687, 044002 (2019)

16. White Paper - World Bank Ranking «Doing business 2020» (2020) https://www.doingbusiness.org/en/reports/global-reports/doing-business-2020

17. Official site of the National Association of Builders NOSTROI (2021): http://nostroy.ru

18. Official site of the Ministry of Economic Development of the Russian Federation (2021): http://economy.gov.ru/minec

19. E. Rybnov et al, E3S Web of Conferences 217, 11010 (2020) 
20. L.G. Selyutina et al, Management of investment activities in the region (Saint Petersburg State University of Economics, St. Petersburg, 2006)

21. E. Pesotskaya et al, Advances in Economics, Business and Management Research 157, 180-182 (2020)

22. N. V. Vasileva et al, Special characteristics of market supply formation in housing development sector and residential buildings reconstruction under the present-day conditions in Russia, in Proceedings of the International Conference on Innovations in science and education, 20-22 March 2019, Prague, Czech Republic (2019)

23. L.G. Selyutina, INZHEKON Bulletin, Series: Economics, 1(28), 5-10 (2009)

24. N. Frolova, et al, E3S Web of Conferences 97, 06003 (2019)

25. D. Rodionov et al, World of economics law, 4-5, 19-30 (2014)

26. E. V. Pesotskaya et al, IOP Conf. Ser.: Mater. Sci. Eng. 698, 077030 (2019) 